\title{
ALOX12 wt Allele
}

National Cancer Institute

\section{Source}

National Cancer Institute. ALOX12 wt Allele. NCI Thesaurus. Code C103925.

Human ALOX12 wild-type allele is located in the vicinity of 17p13.1 and is approximately $15 \mathrm{~kb}$ in length. This allele, which encodes arachidonate 12-lipoxygenase, 12S-type protein, is involved in leukotriene synthesis. 